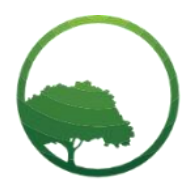

Research in Business \& Social Science

IJRBS VOL 9 NO 3 ISSN: 2147-4478

\title{
Conceptualizing entrepreneurship in human resource management
}

\author{
Amaka Orakwue(a), Osarumwense Iguisi $\oplus_{(b)}$ \\ (a) Department of Entrepreneurship, Faculty of Management Science, University of Benin, Benin City, Nigeria \\ (b) Department of Business Administration, Faculty of Management Science, University of Benin, Benin City, Nigeria
}

Crossref

\begin{tabular}{l} 
A R T I C L E I N F O \\
\hline Article history: \\
Received 03 March 20 \\
Received in revised form 19 April 20 \\
Accepted 23 April 20 \\
\hline Keywords: \\
Entrepreneurship, Human Resource \\
Management, Strategic Human \\
Resource Management, \\
Innovativeness, Entrepreneurial \\
Strategy \\
JEL Classification: \\
J20, J30
\end{tabular}

\begin{abstract}
A B S T R A C T
This paper examines various models of entrepreneurship in the recruiting, managing, and organizing of Human Resources of an enterprise or organization. It adds to the growing body of literature in entrepreneurship by reviewing literature that examines the relationship between entrepreneurship and the Human resource management practice. It examines the theoretical framework that underpins the relationship between HRM and entrepreneurship. The study introduces strategic HRM as an entrepreneurial strategy whereby employees are applied as instruments needed to fully accomplish organizational objectives. It concludes that in starting a new firm or maintaining an already established organization where resources are limited, entrepreneurship and the role of an entrepreneur becomes a crucial management function in the selection and personal development of the human resource competencies. Organizations are therefore encouraged to imbibe the role of entrepreneurship in the managing of Human Resources in order to drive innovativeness, lead change, and make continuous improvements.
\end{abstract}

(C) 2020 by the authors. Licensee SSBFNET, Istanbul, Turkey. This article is an open access article distributed under the terms and conditions of the Creative Commons Attribution (CC BY) license (http://creativecommons.org/licenses/by/4.0/).

\section{Introduction}

The concept and theory of Entrepreneurship has been best introduced by Joseph Schumpeter in 1934. In his theory, Schumpeter conceptualized Entrepreneurship as the process which involves the reformation on various equipment of production, marketing and industrial organizations causing change in the development of new sources of raw material, products, outputs and markets towards economic, social and financial goals. He believes that creativity, innovation and requisite knowledge are significant factors needed for successful entrepreneurship. He further added that such development is not an automatic process and requires a deliberate and active commitment from some agents whom he called -the Entrepreneur, who initiates the process. The entrepreneur is one who provides economic leadership that changes the original conditions of the economy and causing discontinuous dynamic changes in the system. Entrepreneurs are autonomous and motivated by uncertainty which they consider as an opportunity.

According to Dal Zotto and Gustafsson (2007), entrepreneurs are valuable resources to an organization such that they create completely new opportunities for investment, growth and employment through the development of high level creativity. They recognize an opportunity to create a new business and take on related risk in response to unmet market demands and pursue this opportunity turning it into viable, concrete and marketable innovations. Nevertheless, Entrepreneurship is ultimately dependent on some other factors such as the personal quality, talent, education, \&cultural background, cognitive skill and knowledge base of human resources which can drive an inspiration that leads to creativity. Amabile (1996) noted that in order for an inspiration to be a daily driving force and engender continuous innovation within an organization, intrinsic motivation is required which rests on the competences of human resources. The management of the human resources plays a vital role in managerial decision making which affects organizational entrepreneurship; hence, examining the relationship between HRM and entrepreneurship is important

* Corresponding author. ORCID ID: 0000-0003-1708-3351

(C) 2020 by the authors. Hosting by SSBFNET. Peer review under responsibility of Center for Strategic Studies in Business and Finance.

https://doi.org/10.20525/ijrbs.v9i3.692 
(Madmoli, 2016). However, there have been few studies in this field.HR management practice such as promotion, rewarding, compensation, training and development are the factors which when maximally utilized, improve employees' innovation and creativity which boosts entrepreneurship. Following this, an Entrepreneurial team involved in starting a new firm or launching a new product could be either novices (which applies to founders of a new autonomous business) or habitual Entrepreneurs (which applies to founders of several companies) and this can affect the HRM competences (Dal Zotto \& Gustafsson, 2007). Therefore, the team composition of personnel (entrepreneurs or intrapreneurs) who make up an organization is fundamental and the way and manner in which they are to be selected, empowered, developed, motivated and supported, determines the rapid growth and successful performance of the organization.

This paper focuses on the process of development and management of personnel or people resource of an organization who can continuously produce innovation and creativity to the organization. In other words, this paper focuses on the concept of Entrepreneurship as an important tool for building Human Resources Management competences of an organization.

This study concentrates on The Resource Dependency Theory that best examine the relationship between entrepreneurship and Human Resource Management. The theory posits that the lack of unique and non-imitable resources such as human resources, technological or organizational resources that differentiates an organization from its competitors can lead to inefficiencies, noncompetitiveness, and reduce growth potential among organizations (Barney, 1991)

The paper is structure as follows. The first section focused on the concept and origin of Entrepreneurship, and Human Resource Management. The second section reviewed the existing literature on the relationship between Entrepreneurship and HRM. It also discussed the theoretical perspective that underpinned the relationship between the variables. Lastly, the paper concludes.

\section{Literature review}

\section{Theoretical Framework}

The organisation life cycle theory, behaviourial management theory, resource dependency theory, comparative advantage theory, general systems theory, organisational learning theory are some of the theories used in explaining the relationship between Human resource management principles and techniques for people management and entrepreneurship in small entrepreneurial competitive organizations. However, the organization life cycle theory, behavioral management theory, resource dependency theory are discussed in this study and lastly, the resource dependency theory is chosen which underpins the theoretical relationship between human resource management and entrepreneurship in the study.

\section{Organisation Life Cycle Theory}

This theory as propounded by Cameron \&Whetton (1981) characterizes organizational development through various stages in a life cycle from formation, growth, maturity, decline and death. The theory specifics that the collective understanding of an organizational stages of development, how these activities and structures change as the organization grow and mature enables top managers in choosing the appropriate competitive course of action or strategies that either moves the firm further or return it to its previous but more innovative state. This notion of the life cycle of an organization, however, has been opposed theoretically as being distinctly deterministic such that an organization inevitably passes from one stage of development to the other without the actions of management. Lester, Parnell, and Carraher (2003) adopted a five stage approach organizational life cycle consisting existence, survival, success, renewal and decline. This scale develops a scale in order to classify organizations according to the activities associated within each stage of development as determined by top management. Also, it examines the relationship that exists between the organizations' life cycle, competitive strategy and performance. For example, at the maturity or renewal stage of the organization, top management could introduce an organizational structure that supports human resource creativity, innovation, teamwork and high performance, which will withstand pressure from competitors and induce growth and survival. Therefore, for small entrepreneurial organizations, this theory explains the relationship between an organization's life cycle and its competitive strategy as it moves from its formation to decline stage.

\section{The Behavioural Management Theory}

The behavioural management theory as defined by Naylor, Pritchard and Ilgen (1980) describes the use of human resource practice as instruments for shaping the patterns of behaviours of individuals and team members which help to achieve organizational goals and objectives. Understanding and predicting such behaviours help to inform managers in making purposive decisions, and what steps they could take on people management as well as the expected consequences.

In management research, management principles have been developed that addresses the human dimension of work and explains the individual behavior of employees. Schuler and Jackson (1987), examined Porter (1985)'s three generic strategies which describes how organizations pursue competitive advantage depending on its chosen market scope. They posited that organizations match appropriate HRM practice and policies with a chosen generic strategy that will improve work performance as well as productivity. Thus, they posited that organizations pursuing either cost minimization strategy should choose stiff policies while those pursuing an innovation strategy would need to improve the working environment including the resources in order to stimulate new behaviour in 
employees including rewarding long term goals and broad career paths in order to induce and promote positive work behaviour, and also include punishments to control negative behaviours (Rogers, 1983).

\section{Resource dependency theory}

The resource dependent theory as propounded by Pfeffer and Salancik, (1978) explains how organizations can best acquire and effectively utilize scarce resources which not only differentiate them in a competitive market but also these resources are durable, not easily imitable nor substituted. The theory portrays a firm in an open system which depends on the external environment where it derives its resources (financial, physical, technological and labour). It describes the ability of an organization to create an appropriate link with the environment that ensures access to such unique and distinguishable resources which provides benefits such as an enhanced brand name, organization repute, greater employee affinity, boost customers' trust and consequently bringing about competitive advantage and an overall financial performance (Bird, et al, 2007). The theory explains how selecting appropriate resources from the environment can enhance the value and brand image of the products and services of an organization. Human resources are regarded as the core of organizational power. Sustaining a competitive advantage of a growing entrepreneurial firm means selecting a specific HRM strategy that is internally consistent with the core objectives of the organization. However, overdependence on external resources could be detrimental due to the uncertainties that cannot be controlled by the organization (Pfeffer \& Salancik, 1978). The theory also provides a potential for integrating human resource management goals to a company's strategic management.

The Resource Dependency Theory was chosen for the study which best underpins the relationship between entrepreneurship and Human Resource Management. The theory posits that the lack of unique and non-imitable resources such as human resources, technological or organizational resources which differentiates an organization from its competitors can lead to inefficiencies, noncompetitiveness, and reduce growth potential among organizations (Barney, 1991). It provides a framework which explains how organizations draw innovativeness, risk taking attitudes and pro-activeness from the environment through the application of core Human Resource Management strategies. For many entrepreneurial and highly innovative organizations that require exceptional, non-substitutable resources to stay highly competitive in the business environment, human resources becomes a major source of sustained competitive advantage. The resource based theory posits that a higher application of certain human resource management strategies such projecting the right number and category of human capital, matching the right employees with specific organizational goals or training and development of employees can be expected to lead to a higher organizational performance. The theory also supports the concept of the Strategic HRM which involves linking organizational strategy with people management such that the way and manner the firm recruits, selects, places, appraises or rewards employees would be strategically chosen in relation to the desired goals of the firm (such as growth, survival, innovation, merger, closures, diversification goals). Therefore, the culture, attitudes, values and commitment of employees is important to the success of an organization (Dabic, Ortiz-De-Urbina-Criado,\& Romero-Martinez, 2011).

\section{Conceptualizing entrepreneurship}

Entrepreneurship is a concept which describes the activities of an entrepreneur. This concept has increasingly grown in the last decades and has evolved overtime and different authors have different definitions to it. While most authors (for example, (Shane and Venkataraman, 2000), Reynolds, 2005 defines entrepreneurship as the discovery and exploitation of opportunities and the subsequent creation of new profitable activity, often via the creation of a new organization, some others, such as Miller, (1983); Schumpeter, (1934; 1942), focuses on the entrepreneurial spirit which combines the classic theories of exploration, innovativeness, risk taking functions, initiatives and imagination inside or outside an existing organization in creating new opportunities. Inegbehebor (1998) as cited in Oviawe (2010) defines entrepreneurship as ability and willingness of an entrepreneur to recognize opportunities in the face of uncertainties and related risk but are ready to start up a new firm or venture, arrange business deals and taking risks in order to make a profit. Ikeme \& Onu, (2007) argued that Entrepreneurship is a function of seeking investment and production opportunities, organizing an enterprise to take up new production process, raising capital, hiring labour, and employing resources as well as introducing new ventures towards economic, social and financial goals. More so, Covin and Slevin (1999) defined entrepreneurship in relationship to three components namely; innovativeness, risk taking and proactiveness which results in the creation of new firms (startups) or corporate entrepreneurship.

According to Putari (2006), entrepreneurship involves the role of an agent (entrepreneur) who unites all means of production and discovers in the value of the products, the reestablishment of the entire capital he employs, the value of the wages, the interest, and rent, which he pays, as well as profits belonging to himself thereby viewing entrepreneurs as change agents. Nevertheless, Shane, (2004) argues that entrepreneurship has evolved over time to include undertakings not necessarily related to business or financial activities. He posits the entrepreneurship could involve some political or social aspects of entrepreneurial activities such as the setting up of a youth support or empowerment programmes or imbibing creativity, innovation and globalization through introducing the concept- cultural innovation amongst students in schools. Joseph Schumpeter's "creative destruction" theory is perhaps the first and most outstanding and coherent account of entrepreneurship. According to Schumpeter (1934), the entrepreneur is the individual who, introduces new products or services, production methods, processes or technologies, reorganization of an industry, identifies new export markets or sources of supply, creates new types of organization or industrial combinations causing a change in the economy from its status quo through a process termed 'creative destruction'. 
According to Soyibo (2016), entrepreneurship is the process of identifying an opportunity related to needs-satisfaction and converting it to a product or service thereby creating wealth and value for the people. From the work of Soyibo, entrepreneurship can be conceptualized to mean the process and activities undertaken by entrepreneurs directed at capturing value, associated with business opportunities. Dal Zotto \& Gustafsson (2007) posited that entrepreneurship can also be achieved through the creation of new organizations or the pursuit of innovation or inventions within an already existing firm (intraprenuership). Furthermore, Esomonu cited in Oviawe (2010) opined that entrepreneurship can be seen as the effective manipulation of human intelligence to develop a new venture, company, or the application of a new approach or ideas to a previous or already existing business. Oviawe (2010) further noted that the definition of entrepreneurship according to the National Directorate of Employment (NDE) involves the recognition of business opportunities, adapting to change, mobilization of resources and persistence in exploiting an opportunity.

In the conceptual framework of Entrepreneurship, the term can be viewed as a management process, as imagination or creativity, as innovation, alertness and discovery, as charismatic leadership, as that consisting of judgmental decision-making etc. This study examines entrepreneurship as management below while introducing its role in Human Resource Management.

\section{Entrepreneurship as management}

According to Ibrahim and Shailendra, (2003), in entrepreneurship curriculum, the phenomenon has often been viewed as small business management where entrepreneurs are as the managers of small, family-owned businesses or start -up companies. The theory of Entrepreneurship under the management approach considers the day to day management task of small business owners, the relationships with venture capitalist and other sources of external funding, marketing and product development or improvement and how they organize and manage their assets.

Entrepreneurship is considered as a management process by which group of individuals, starting a new firm or launching a new product or market, accept risks and pursue an opportunity obtained by turning creative ideas into innovation. However, in order to ensure a continuous motivation to pursue such opportunities in the management of small and new business and also large and established businesses, the process of selection, and personal development of the human resource is very crucial for the successful performance of the organization. Starting a new firm, were resources are limited and entrepreneurs usually do not have human resource competences, it is appropriate for new firms to concentrate on acquiring competent personnel who can deliver innovativeness, lead change and are continuously commit to quality improvements in the organization.

\section{Human resource management (HRM) and strategic human resource management (SHRM)}

The development and management of the human resource of an organization form an important mechanism for achieving competitive advantage and organizational performance in the ever changing competitive market place (Madmoli, 2016). HumanResource Management is an integral part of management and involves the systematic process of hiring, training and development, rewarding and maintaining organization's core personnel in order to motivate and strengthen organizational performance. According to Storey (1995), Human Resource Management is a distinctive approach to employment management which seeks to achieve competitive advantage through the strategic deployment of a highly committed and capable workforce, using an integrated array of cultural, structural and personnel techniques. Byars and Rue (2004) view HRM as the activities designed to provide for and coordinate the human resources of an organization. The performance and growth of every new firm or business lies in investing in valuable human resource through personnel development or appropriate leadership. HRM includes all activities related to the recruitment, development and gratification of the personnel of an organization (Dabic, Ortiz-De-Urbina-Criado, \& Romero-Martinez, 2011). It involves a process of ensuring that the staffing organization has the right number and quality of people, doing the right jobs at the right time (Itika, 2011).

Dabic et al., (2011) espoused that Strategic Human Resource Management gives organizations the internal ability to adapt and adjust to the changing organizational environment by developing effective HRM policies and practice which align with organizational strategic goals towards a source of sustainable competitive advantage. In addition, Harrison, (1993), defines strategic human resource management as "an overall and coherent long term planning and shorter term management, control and monitoring of an organization's human resources so as to gain from them the maximum added value and best position them to achieve the organization's corporate goals and mission". The human capital of an organization which relates to the skills, creative abilities, knowledge and expertise acquired by the human resources of an organization is a significant resource which when managed effectively leads to a positive effect on growth, productivity, service delivery processes and performance. More so, the HRM in this context can be viewed as a tool used in getting the best possible results in an organization working through people. Thus, the creation of new organizations or businesses and the building of innovation and talents can be effectively achieved where the human resource is properly planned, organized, oriented, selected, trained, developed, appraised and adequately compensated in the best way that will result in the emergence and development of the right core competencies and organizational capabilities which serve as the basis of value creation. Hence, Organizations need to create and design HRM strategies that would maintain better human relations in order to foster entrepreneurial goals and objectives. 


\section{HRM and entrepreneurship}

While a number of previous studies have examined HRM (Cardon \& Steven, 2004) and entrepreneurship(Schumpeter, 1934) independently, few studies have dealt with examining the relationship between the two areas jointly such as Madmoli, (2016); Dal Zotto and Gustafsson, (2007); Castrogiovanni, Urbano and Loras, (2011). Nevertheless, current studies in the literature such as Dabic, Ortiz- De-Urbina- Criado, \&Romero-Martinez (2011) have reviewed and analyzed studies to determine how much work has been done in this line of research, to consolidate on the literature and to identify the limitation in these studies in order to improve on future research. Though some of the studies such as Dal Zotto and Gustafsson, (2007) appear to be limited in sound descriptive analysis and sparse in analytic research, they present good explorative study on the subjects and prescription for future lines of research.

\section{Discourse on HRM and Entrepreneurship}

HRM is an important driver of entrepreneurship hence there is a need for research that addresses the contributions that HRM makes to a firm's ability to accept risk, be innovative and be proactive. Dabic, Ortiz- De-Urbina- Criado, \&Romero-Martinez (2011) reviewed 62 articles which examined the relationship between HRM and entrepreneurship. They searched for 42 articles using the ABI information database and 20 articles from the business source complete database. The paper aimed to describe published works, examine the previous literature and identify any gaps in the research that could motivate further research. The study found out that most papers which examined the duo were empirical though have been published since the year 2000 till 2008. Again, of the articles on entrepreneurship 58\% dealt with corporate entrepreneurship (for example, Hayton,2005) or small and medium scale enterprises (SMEs) such as Heneman, Tansky and Camp (2002); 34\% dealt with startups such as Zoltan and Catherine, (2004) and only 8\% such as Dal Zotto and Gustafsson, (2007) focused on the combined viewpoint. Furthermore, $69 \%$ of the articles on HRM dealt with HRM as a whole (for example, Dal Zotto and Gustafsson, 2007) while about 31\% focused on specific aspects of HRM such as training, employee commitment and motivation etc (such as Camelo-Ordaz, Garcia-Cruz, Sousa-Ginel and Valle-Cabrera (2011) in relation to entrepreneurship. They concluded that more recent work should be done in the area to promote better understanding of the role of HRM in fostering entrepreneurship and to fill the gap in the literature. Madmoli (2016) investigated the relationship between HRM and organizational entrepreneurship in Iran using knowledge sharing by middle managers as a mediating variable. The study was an applied research and utilized a sample of 384 managers and employees selected using the Cochran's sampling formula. Data was collected using an author synthesized questionnaire and was analyzed using the path analysis. The study found a positive and significant relationship between the variables and an improved relationship with the mediating role of knowledge sharing practice among middle managers who help bridge the knowledge gap between employees and top managers. Hayton (2005) reviewed empirical studies on human resources as drivers of corporate entrepreneurship, although this study did not dwell on starting and growing firms. Although the study found a consensus on how HRM contributes effectively to corporate entrepreneurship, the empirical evidence indicated a mixed finding and identified two central themes namely, the individual risk acceptance and the encouragement of discretionary entrepreneurial contributions which need to be addressed in seeking a theoretical explanation on the relationship.

Entrepreneurship researchers, however, have been discouraged in conducting researches in SMEs in particular small startups and growing organizations because it is seen that only larger organizations have a formalized HRM department. More critical is the development of the human resources of a firm at its early stage or founding stage. Despite these limitations of new entrepreneurial firms, a number of studies on the role of HRM in startups have been conducted. Castrogiovanni, Urbano \& Loras (2011) examined the relationship between firm entrepreneurship and HRM in small and medium scale organizations and found out that HR practice and leadership styles of management influences the level of creation of new firms and innovation among SMEs. Zoltan and Catherine, (2004) also demonstrated in their work that survival as well as growth of new firms strongly depends largely on their endowment with qualified and experienced personnel which is related to the level of education and knowledge spillover effects. From the growing body of research, HRM in small but rapidly growing firms differ both from slowly-growing firms and the large companies (Heneman, Tansky \& Camp 2002). Dal Zotto and Gustafsson, (2007) noted that at the early stage of a growing firm, there may be issues regarding the sufficiency of qualified and experienced personnel and hence it is quite impossible for these firms to engage in elaborate and expensive HRM practice (such as formal training and development programmes. Also, these firms may be subjected to the liabilities of smallness and newness, which is often demonstrated through the scarcity of resources including employer's legitimacy. Camelo-Ordaz, Garcia-Cruz, Sousa-Ginel and Valle-Cabrera (2011) investigated the effect of HRM practice on knowledge sharing and innovation with effective commitment of employees as a mediating variable. They found out that HRM practice has no effect on knowledge sharing with the mediating role of effective commitment. Lee, Peris-Ortiz, and Fernandez-Guerrero, (2011) analysed various concepts of entrepreneurship and contributions to human resource practice in a Spanish firm - Montalt-Valencia, a FordSpain car dealer. They conducted a confirmatory study and found out that the continual renewal and steady improvements in HR techniques fortifies its innovative capacity and hence may lead to a transformation of the levels of organizational efficiency and commitment to the firm.

Furthermore, in comparison with established firms, new firms operate a less formal personnel management system where the owner usually handles the payroll systems, record keeping and other clerical work but are more innovation-oriented regarding human resource planning, compensation strategies, and add value to the management of their organizations. Asides the human resource 
functions which include recruitment, selection, and training, Dal Zotto and Gustafsson, (2007) stressed that the extremely necessary function that must be included in the human resource management of an entrepreneurial or new firm or business is the salary bookkeeping, as well as payments for salary taxes and health insurances. Consequently, as the firm grows, human resource management strategic functions such as leadership, personnel motivation and development, compensation as well as performance management, developed based on organizational vision, mission, policies, goals and objectives would need to be aligned with the firm strategies and especially those concerning product portfolios, marketing and financing in order to generate a competitive edge. Tang,Wei, Snape, and $\mathrm{Ng}$ (2014) proposed a model linking strategic HRM with entrepreneurship. Also, the relationship between the political and relational skills of human resources and organizational development was examined. The study eventually found out that HRM significantly affects entrepreneurship and the relationship between the HR skills and organizational development is affected by a partially developed leadership style.

From the above discourses of literature which examined the relationship between HRM practice and entrepreneurship, this paper posits that for an effective growth and success of a new firm or entrepreneurial firm, the core competences of the HRM which is made up of individuals who can undertake risk and recognize opportunity, creativity ideas and turn them into value productive and innovative goals should be harnessed. The preceding sections discusses the HRM functions such as Human Resource Resourcing/Planning (HRP), Recruitment, Compensation, Leadership, Training and Development, Personnel Motivation, Performance Management etc and other actors such as the outsourcing of HRM and the use of contingent labor which are critical for new and emerging entrepreneurial firms.

\section{Entrepreneurship through human resource planning (HRP)}

Human resource planning according to Itika (2011) is a quantitative and qualitative process of ensuring that the organization has the right people with necessary and adequate skills, placed at the right time doing the right job. It involves planning for the number and quality of employees required under various job categories and to make sure that staffing process such as acquiring, utilizing, rewarding, promoting, developing, retaining, transferring and downsizing are effective. The process of HRP or human resource acquisition is concerned with satisfying the HR needs according to the changing conditions of the business and it should be guided by the business strategies, goals, objectives, missions and policies. For example, if the organization is venturing a new production line in the next two years, it would need to plan to recruit and re-train staff who are qualified and can fit into this new production line in order to make sure employee move in the right perspective in securing organization's competitive advantage.

\section{Entrepreneurship through recruitment}

According to Dal Zotto and Gustafsson (2007), the goal of every firm either emerging or established is to continuously improve their competitiveness in the market, and as they grow and mature, their human resource requirement needs change rapidly. The recruitment and selection of the right people with the essential and appropriate skill and competence who have the ability to fit into organization needs at different growth levels is a key component to the success of an organization. This can further enhance the economic efficiency of an organization, increase their market share or lead to the introduction of new and improved products, services or markets through innovation.

\section{Entrepreneurship through compensation}

Compensation is another vital component of the human resource management function in which entrepreneurial firms can create competitive advantage through acquiring core talents. Entrepreneurial firms need to have a structure in their HR policies and practice in order to adequately reward creativity, innovativeness, willingness to take risks, cooperation and uncertainty. According to Cardon and Stevens (2004), reward systems have significant impact on employee job satisfaction and it is usually based on bonuses which are both in profit and stock sharing. Bengtsson and Hand (2013) in their study examined the compensation practices across 1,809 entrepreneurial firms controlled by founders and venture capitalists (VC). They found out that employee compensation is determined by the degree to which venture capitalists versus founders control the business. They found out that VC controlled firms pay their non-founder employees higher cash salaries, provide stronger financial and equity incentives and had more formal pay policies in place. On the other hand, the founder employees earn lower cash and experience weaker financial incentives. It was concluded that the compensation differences arose because the preferences and capabilities of controlling shareholders significantly increased the quality of the human capital attracted and retained by the firm. Most entrepreneurial firms deviate from the traditional hierarchical organizational structure such that financial rewards are not indication of employee status. In such cases, firms provide a multidimensional reward system based on successful innovativeness or creativity. Furthermore, Graham, Murray, and Amuso (2002) added that the satisfaction derived from having an ownership stake in the business creates a feeling of reward. Retaining employees through strategic policies such as career path planning, pay and benefits; instilling good reward systems and employee-employer relationships, creating a feeling of ownership interests and also engaging in operational strategies, like re-training, re-deployment or re-location help in ensuring employees move in the right perspective.

\section{Entrepreneurship through leadership, training and development}

Getting work done rightly through people all the time in an uncertain environment is most times difficult. However, the leadership role is critical where the focus is on the enthusiastic participation of the people led with the aim of achieving improvement, innovation 
and change. David (2016) posits that improvements are easiest to achieve if they are made by people who are responsible for the processes being improved. Furthermore, David (2016) espoused that the entrepreneur identifies an opportunity niche and engages such employees who are motivated to work as hard as they are capable of, who are committed to make a change, determined to take risk, act proactively and are fully engaged with the process. The concept of Entrepreneurial Leadership management involves an entrepreneur's ability to effectively deal with opportunities through the dynamics of an organizational setting which determines an organization's performance. It involves breaking new grounds, assisting people to exploit new opportunities and working beyond what is known.

\section{Entrepreneurship through performance management}

The performance management of employees is another crucial aspect of HRM that fosters entrepreneurship. However, very little research has been conducted in this area (Cardon \& Stevens, 2004). In rapidly growing entrepreneurial firms, employee performance is appraised through financial incentive and stock options rather than through other traditional HRM measures. Heneman, Tansky amd Camp (2002) posit that small and medium entrepreneurial firms oriented towards innovation, creativity and flexibility are most times characterized by high employee turnover. This is expected due to the gradual in flow of new skill, expertise and knowledge gotten from new employees being admitted. However, Baron and Hannan (2002) espoused that a continuous and intense employee turnover would spell detrimental to a fast-growing firm as it could lead to loss of intellectual property of the firm especially in knowledge - intensive firms. Such firms should be able to include measures of attracting and retaining their valuable organizational knowledge and expertise.

\section{Entrepreneurship in personnel motivation}

According to Lorincová, Štarcho, Weberová, Hitka, and Lipoldová (2019), the recruitment and hiring of employees in small entrepreneurial firms is one laudable step but bolstering their performance and productivity through continued trained and motivation can be challenging. Research indicates that a "well-motivated, highly skilled workforce is a determinant of a small firm's ability to remain competitive in the contemporary business environment" (Hornsby \& Kuratko, 2003). Highly motivated employees or managers apply energy, commitment, and creativity to their jobs in order to promote the company in positive ways and help to build the values of the enterprise. Feldman (2018) espoused that some issues that can possibly drain an employee's motivation and productivity and consequently affect business performance include low self-confidence of an employee, employees' lack of interest in the subject matter, fear of failure, employer's low expectation for success, amongst others. However, conscious and daily actions from management to creating employee job satisfaction such as job specific training, compensation, job security, opportunities to use skills and abilities, relationship with immediate supervisor, benefits (especially health care and retirement benefits), organization's financial stability, and the job itself, would motivate them to improve productivity. Employee training, a factor that has been shown to correlate highly with employee satisfaction and turnover, is an important determinant of growth, though SMEs are sometimes reluctant to train employees who may not stay (Devins \& Johnson, 2003). Another motivating factor is money and other reward systems such as bonuses, promotion play an important role in engendering improvement in employee satisfaction and performance, as well as organizational productivity. Other motivating factors include Recognizing Good Performance, providing Professional Development Opportunities, fostering a relaxed working environment. Ghassemieh, Thach and Gilinsky (2005) added that setting realistic and achievable goals, appropriate workload definition, employee engagement, appropriate empowerment, responsibility, feedback, supplying adequate work equipment, expressing the positive personality features of a supervisor, appropriate leadership style, correctness by senior staff and company, and providing relevant information are considered to be other important motivation factors.

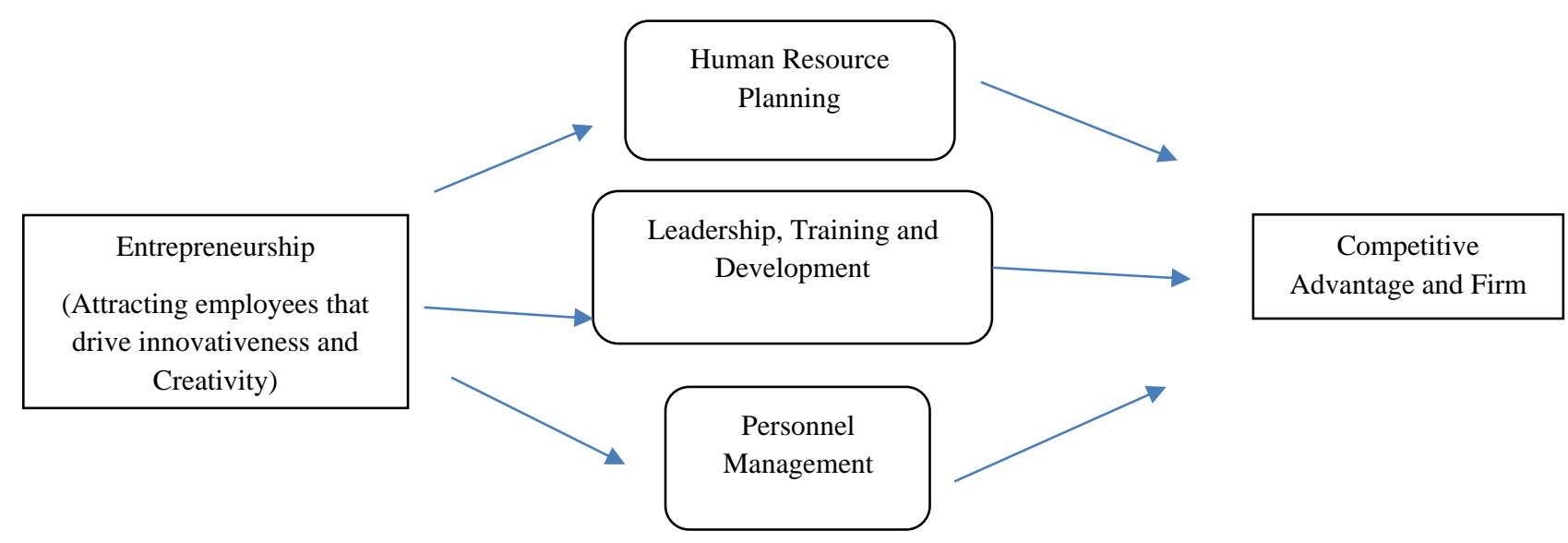

Fig.1: Conceptualizing entrepreneurship in human resource management; Source: Researchers' Compilation, (2020)

Managers attract and select employees who drive innovativeness and creativity to enhance firm competitiveness and performance. 


\section{Conclusions}

The study examined the concept of HRM and entrepreneurship. It also examined the role of HRM towards actualizing entrepreneurship and the relationship between the duo concepts. While the HRM of an organization has been described as the systematic process of acquiring, developing, and maintaining of an organization's people resource towards a set goal, entrepreneurship relates to the process of creating value by bringing together a unique set of resource in order to exploit an opportunity. The study posited that effective HRM is crucial for new organizations in order to achieve higher level of entrepreneurial success and compete in the dynamic business world. In other words, Entrepreneurship can be enhanced and improved with the distinctive role of HRM. From the literature, entrepreneurship and HRM practice work hand in hand and corporate entrepreneurship can be used as a proxy for the effectiveness of HR management. The study also espouses that the choice of human resources or the strategic use of HRM practice is a source of entrepreneurship and organizational competitive advantage. The study also supported the resource dependency theory which espoused that entrepreneurial firms draw valuable and critical resources from the environment by acquiring the right personnel who can bring creativity, innovation and novelty to business operations and also through leadership, have the ability to deal decisively with recognized opportunities and encourage other individuals to commit to effective organizational success. This theory also lay credence to Strategic Human Resource Management. Lastly, as entrepreneurial firms continually grow and market opportunities present themselves, organizations are expected to continuously adjust their human resource needs in selecting the right human resource that have the capacity to drive competitiveness and organizational performance.

\section{References}

Amabile, T. M. (1996). Creativity in Context. Boulder Co: Westview Press.

Barney, J. B. (1991). Firm resources and sustained competitive advantage. Journal of Management, 17(1), 99-120. Retrieved on 11th July, 2016 from: http://dx.doi.org/10.1177/014920639101700108

Baron, J.N. \&Hannan, M.T. (2002). Organizational blueprints for success in high-tech start-ups: Lessons from the Stanford project on emerging companies. California Management Review, 44 (3), 8-36

Barringer, B.R, Jones F.F., \& Neubaum, D.O. (2005). A quantitative content analysis of the characteristics of rapid-growth firms and their founders. Journal of Business Venturing, 20, (5), 663-687

Bengtsson\& Hand (2013). Employee compensation in Entrepreneurial companies. Journal of Economics and Management Strategy, $22(2), 1-11$

Bird, R., Hall, A., Momente, F. \& Reggiani, F. (2007). What corporate responsibility activists are valued in the market. Journal of Business Ethics, 76 (1), 189- 206.

Byars, L. L. \&Rue, L. W., (2004). Human Resource Management. Seventh Edition.Front Matter Preface: The McGraw-Hill Companies

Camelo-Ordaz, C., Garcia-Cruz, J., Sousa-Ginel, E., \& Valle-Cabrera, R. (2011). The influence of human resource management on knowledge sharing and innovation in Spain: The mediating role of affective commitment. The International Journal of Human Resource Management, 22 (7), 1442-1463.

Cameron,K., \&Whitton, D.(1981), Perceptions of organizational effectiveness over organizational life cycle. Administrative Science Quarterly, 523(26), 68-82.

Cardon, M. S. \& Stevens, C. E. (2004). Managing human resources in small organizations: What do we know. Human Resource Management Review, 14, (3), 295-323.

Castrogiovanni, G. J.,Urbano, D., \& Loras, J. (2011).Linking corporate entrepreneurship and human resource management in SMEs. International Journal of Manpower,32 (1), 34-47.

Covin, J. G. \& Slevin, D. P. (1989). The strategic management of small firms in hostile and benign environments. Strategic Management Journal 10(1),75-87.

Dabic, M., Ortiz-De-Urbina-Criado, M., \& Romero-Martinez,A. (2011). Human resource management in entrepreneurial firms: A literature review. International Journal of Manpower, 32 (1), 14-33

Dal Zotto, C., \&Gustafsson, V. (2007). Human Resource Management as Entrepreneurial Tool. Rowena Barret and Susan Mayson (Ed.), International Handbook of Human Resource Management and Entrepreneurship, Edward Elgar Publishing.

David, P. (2016). Introducing Leadership (Second Edition). Making Things Happen.

Devins,D., \& Johnson, S. (2003).Training and development activities in SMEs. International Small Business Journal, 21 (2), 213.

Feldman, M. (2018). How Small Business Can Motivate Employees. Retrieved from https://startupbros.com/how-small-businesscan-motivate-employees-to-boost-productivity/

George, J. \& Jones, G. (2005). Understanding and Managing Organizational Behavior, 4th Edition, Pearson Prentice hall, Upper Saddle River, NJ

Ghassemieh, G., Thach, L., \& Gilinsky, A. (2005). Does my business need a human resources function. A decision-making model for small and medium-sized firms. New England Journal of Entrepreneurship, 8(1), 25-36 
Graham, M.E., Murray, B. \& Amuso, L. (2002). Stock-related rewards, social identity, and attraction and retention of employees in entrepreneurial SMEs. In J. Katz and T.M.Welbourne (Eds.), Managing people in entrepreneurial organizations, (5). Amsterdam: JAI Press, pp. 55-81

Harrison, R. (1993). Diagnosing Organizational Culture: Trainer's Manual. Amsterdam: Pfeiffer \& Company.

Hayton, J.C. (2005). Promoting corporate entrepreneurship through human resource management practices: A review of empirical research. Human Resource Management Review, 15 (1),21-41.

Heneman, R.L., Tansky, J.W. \& Camp, S.M. (2000). Human resource management practices in small and medium-sized enterprises: Unanswered questions and future research perspectives. Entrepreneurship Theory and Practice, 25(1), 11-26.

Hornsby, J., \& Kuratko, D. (2003). Human resource management in U.S. small business: A replication and extension. Journal of Developmental Entrepreneurship, 8(1), 73.

Ibrahim, G., \&Shailendra, V. (2003). Defining the role of the entrepreneurs in economic thought: Limitations of mainstream economics. Working Paper, Nottingham Business School.

Ikeme, A. I., \&Onu, V.C. (2007). Creativity, Innovation and Entrepreneurship: Implication for Youths and Government. A Paper Presented at the Annual Conference of the Psychological Association, University of Nsukka, Nigeria.

Itika, J. S. (2011). Fundamentals of human resource management: Emerging experiences from Africa African Public Administration and Management series, 2 (1), 1-254. University of Groningen / Mzumbe University

Karadjova-Stoer, G.,\&Mujtaba, B. (2009), Strategic human resource management and global expansions: Lessons from the euro disney challenges in France. International Business and Economics Research Journal 8(1), 69-78.

Lee, S.,Peris-Ortiz, M.,\& Fernandez-Guerrero, R. (2011). Corporate entrepreneurship and human resource management: Theoretical background and a case study. International Journal of Manpower, 32 (1), 1-10

Lester, D. L., Parnell, J. A., \& Carraher, S. (2003). Organisational life cycle: A five stage empirical scale. International Journal of organizational Analysis, 11 (4), 1-17.

Leung, A., Zhang, J., Wong, P.K., \& Foo, M.D. (2006). The use of networks in human resource acquisition for entrepreneurial firms: Multiple "fit" considerations. Journal of Business Venturing, 21(5),664-686

Lorincová, S., Štarcho, P., Weberová, D., Hitka, M., \& Lipoldová, M. (2019). Employee motivation as a tool to achieve sustainability of business processes. Sustainability, 11(1),3509.Retrievedfrom http://www.mdpi.com/journal/sustainability

Madmoli, Z. (2016). Investigating the relation between human resource management and organizational entrepreneurship: The mediating role of knowledge sharing by middle managers (case study: Ahwaz Pipe Manufacturing Company). Retrieved from: http://www.ijhcs.com/index.php/ijhcs/index

Martins, E.C. \& Terblanche, F. (2003). Building organizational culture that stimulates creativity and innovation. European Journal of Innovation Management, 6(1), 64-74.

Naylor, J.C., Pritchard, R.D., \&Ilgen, D.R. (1980), A Theory of Behavior in Organizations, New York: Academic Press.

Obasan, K. A. (2014). Impact of Human Resources Management on Entrepreneurship Development. Economica, 10, (1), 83- 93.

Pfeffer, J., \&Salancik, G.R. (1978). The External Control of Organisations: A Resource Dependence Perspective. New York, NY: Harper and Row

Porter, M. E. (1985). Competitive Advantage. New York: Free Press.

Putari, V. (2006). Evolution of Entrepreneurship. Retrieved from: http://www.managementparadise.com/forums/entrepreneurship/1118-

Rogers. E.M. (1983). Diffusion of Innovations. New York: Free Press.

Schuler, R.S. \& Jackson, S.E. (1987). Linking competitive strategies with human resource management practices. Academy of Management Executive, 1(1), 207-19

Schumpeter, J. (1934). The History of Economic Development. Cambridge, MA: Harvard University Press.

Shane, S. (2004). A general theory of entrepreneurship: The individual- opportunity nexus. International Small Business Journal, 22 (2), 206-216. Retrieved from: https://www.researchgate.net/publication/291798010

Storey, J. (1989). From personnel management to human resources management. In: J. Storey, Ed., New Perspectives in Human Resources Management. London: Routledge.

Swiercz, P.M., \& Lydon, S.R. (2002). Entrepreneurial leadership in high-tech firms: A field study. Leadership and Organizational Development Journal, 23 (70), 380-389.

Tang, G., Wei, L., Snape, E., \& Ng, Y. (2014). How effective human resource management promotes corporate entrepreneurship: evidence from China. The International Journal of Human Resource Management 26(12), 1586-1601.doi: 10.1080/09585192.2014.953973

Walsh, A. (2018). Outsourcing HR for Small Businesses. Retrieved from: https://waterwelljournal.com/outsourcing-hr-for-smallbusinesses/

Zoltan, A. \& Catherine, A. (2004). New firm survival and human capital. Discussion Papers on Entrepreneurship, Growth and Public Policy. Germany : Max Planck Institute for Research into Economic Systems Group Entrepreneurship, Growth and Public Policy 